\title{
EIDETICS OF THE HUMAN ART IN THE CONTEXT OF THE NEUROART
}

\section{Karpov V. V.}

\section{INTRODUCTION}

In recent decades, humankind has demonstrated unique advances in technological breakthroughs, which resonates with the areas of research of the past century. On the one hand, penetration into the depths of the human brain is activated, and on the other - in the height of stellar hyperspace. Against this background, the theme of immersion in the boundlessness of the subconscious, which is most clearly manifested in the creative initiations of the human imagination, has sounded quite real. Thus, there is a new direction of scientific research aimed at identifying the deep levers of brain activity, aimed at reflecting the surrounding world in a creative act - "neuroesthetics." The study of the evolution of the creative progress of humanity from the standpoint of neuroaesthetic generalizations is particularly relevant because it expresses and explains the fundamental changes in the context of the artistic reflection of the human environment. The consequence is the problem of understanding the nature of human creativity, the possibility of creating internal images, and their extrapolation, which translates into a new direction of scientific interest - the "neuroart." The neuroart is represented by the process of biological transformation of reality into imaginary internal images that are formed in the human brain based on the functionality of neural networks, the reflection of internal thought actions, and psychological experiences in new images. Neuroart also represents the influence of art on the biochemistry of man and the production of his code of art an indoctrinate method of art. Material evidence of this process is the artistic creativity of humans in a variety of styles and genres.

\section{Eidetic reflection of the world: from primitive society to the present}

The challenge of the modern hyper-information world is the apparent dominance of economic levers, and therefore, the cultural industry comes to change the culture, as a phenomenon of human development, as a process of influence on society, to improve the individual sense of creation - unification, standardization, globalization, universalization in the context of the rapid growth of socio-cultural interactions ${ }^{1}$ [13]. However, at all stages of

\footnotetext{
${ }^{1}$ Levi-Stros, Zh.-K. (1999). Pervobytnoe myshlenie. Moskva, p. 35.
} 
civilizational development, the most characteristic feature of the deepest essence of an individual was an unconscious desire for creativity, the reflection of images that reproduced the surrounding world, which symbolized the attitude to invisible celestial entities, to the imagination.

The research aimed at the study of paleolithic art by scientists can be divided into several directions, among which the structural-semiotic approach is characterized by the understanding of the studied massif as a sign system and advocates the liberation of paleolithic art from direct ethnographic parallels. In the study of the problem of the cultural industry, we note the importance of a neuropsychological approach that understands paleolithic signs, pictures of the inner imagination, and which were subsequently projected onto the walls of caves. The significance of the art of ancient individuals is discussed by S. Yatsenko ${ }^{2}$ [21] and A.D. Stoliar, who came to understand the origin of art from the perspective of the neuroart with the help of the terminological definitions of that time ${ }^{3}$ [20].

Finding the answer to the question of the emergence of fine art in the primordial period is not the only a critical problem in understanding its place and role in the system of cultural values of ancient man, but also obtaining its root causes, the essence of the evolutionary "explosion" that led to the emergence of art. Artistic analysis of rare and very remote monuments leads to the consciousness of the original artist.

Gradually, the evolution of people as an individual occurred, complicated and improved its biological, psychological, social, and cultural aspects of life. It would seem that in the course of this civilizational progression from primordial times to the present, human society should finally achieve prosperity and ensure all benefits for the population of our planet. However, the history of the last 100 years shows the opposite, so it is essential to distinguish the characteristic features of the most critical cultural periods, which will not only outline the general trends of different sections but also identify structural models of the variational thinking of humankind.

In recent decades, a great deal of scientific research has been devoted to establishing the concept of culture. Still, the overall strategy has been searching for universals in it, that is, to identify those phenomena that, despite the diversity of customs and traditions of different ethnicities around the world, would at all times prove convincing. A detailed review of this methodology is present in Clifford Geertz's work "The Interpretation of Cultures" ${ }^{4}$ [5], but the scientist rejects this line of research and offers the own solution to the problem.

${ }^{2}$ Yatsenko, S.A. (2017). Iskusstvo u poroga inogo mira // Vestnik Rossiyskogo gosudarstvennogo gumanitarnogo universiteta, № 10. Pp. 269 - 279.

${ }^{3}$ Stolyar, A.D. (1985). Proiskhozhdenie izobrazitel'nogo iskusstva. M.: Iskusstvo, p. 21.

${ }^{4}$ Girts, K. (2004). Interpretatsiya kul'tur. Moskva, p. 200. 
He writes that the most effective means of analyzing a culture is to interpret it as a purely symbolic system - by isolating its elements, revealing internal relationships between these elements, with the subsequent characterization of the entire system according to its central symbols, around which it is organized, with its underlying structures, the external expression of which it is, and the ideological principles on which it is based.

This formulation of culture leads to a new definition of human and focuses not on the general empirical aspects of his behavior in different places and at different times, but on the mechanisms by which the field of the person's indefinite innate capabilities is narrowed down and concretized into real action. Thus, why does a person choose the one out of the thousands of different options? The mentioned fact is partly determined by the circumstances in which a particular individual and the dominant symbolic systems that exist in society. That is why K. Hirz proposes to view culture not merely as specific models of behavior (customs, traditions, etc.), but as a set of control mechanisms-rules that are called "programs" in computer engineering.

In this context, a person becomes an "animal," literally dependent on various non-genetic control mechanisms or "cultural programs" that determine behavior. Yet, in its cultural development, the society demonstrates multiple forms of organization of society, which in K. Hirtz's formulation are based on three fundamental pillars: ideological principles, basic structures as forms of interaction between system elements and central symbols, and the aspects of culture. If we consider the human behavior as a mediator between these three milestones, and K. Hirz emphasizes that this is where cultural forms appear alongside various artifacts and mental states, then one can construct a scheme of the socio-cultural system and its historical genesis:

1. Ideological principles aimed at cultivating the personality as the center and driving force of the social network and its functioning.

2. Basic structures, such as worldview dominant, archetypes and symbols, means of communication and operation of the society, defined by ideological principles.

3. Elements or cultural-artistic forms that reflect the priorities of society in the context of its aesthetic inquiries and ideas.

We trace the gradual change of priorities if we take into account the European area:

Pre-Christian society (primitive society and antiquity).

1. Ideological principles: polytheism - a pantheon of pagan gods.

2. Basic structures: mythology and ritual as the basis of the communication of society.

3. Elements or cultural-artistic forms: the principles of primitive art, based on characteristic eidetic expressiveness with the subsequent formation of the canon of beauty and suitability in all kinds of art in ancient times. 
Middle Ages.

1. Ideological principles: monotheism with the canonization of Christianity.

2. Basic structures: Holy Scripture and ordinance as the undeniable imperative of human existence.

3. Elements or cultural-artistic forms: the aesthetics of Christian sacred art, the absolute superiority of the spiritual over the physical.

Renaissance introduced the process of secularization and the exaltation of the human being as an individual, which inspires the emergence of new cultural forms into Christian society.

1. Ideological principles: Monotheism and humanistic ideas.

2. Basic structures: worldview anthropocentrism, secular artistic background, and theatricality of social relations.

3. Elements or cultural-artistic forms: The aesthetics of art from the

Renaissance to Romanticism develops within the variability of styles but is based on their constructiveness and certainty of essential characteristics. The vector of these historical changes is symptomatic: from the acceptance of "Man is the measure of all things" in the Renaissance - despite the baroque dualism of good and evil in humans, despite the ideal of vir eruditus, a man enlightened in Classicism - to the messianism of the artists in the age of Romanticism, bowing to the power of inspiration.

At the turn of the nineteenth and twentieth centuries, due to the advancement of science and the disappointment of society in ideals, a transgressive transition beyond the established traditions was observed in the culture, which led to a dramatic change in value orientations.

1. Ideological principles: Human unconscious.

2. Basic structures: The world as Text and Intertext, social game, and invariants of worldview, which go beyond the formative moral and artisticaesthetic norms, change of concepts.

3. Elements or cultural-artistic forms: destructiveness, commensurate with the artistic principles of primitive society based on the eidetic expression.

The scientific progress of the late twentieth century leads to the following consolidation of the facets of human existence:

1. Ideological principles: The human brain is like a neuro system.

2. Basic Structures: the world as Screen, technology, shows, and glamor ${ }^{5}$ [1] as a dominant in the globalized social space.

${ }^{5}$ Bezughla, R. I. (2019). Ghlamur u jevropejsjkij khudozhnij kuljturi: istorychna dynamika ta formy : dys. na zdob. nauk. stup. d. myst. : spec. 26.00.01 - teorija ta istorija kuljtury (mystectvoznavstvo). K.: Nacionaljna akademija kerivnykh kadriv kuljtury i mystectv, p. 291. 
3. Elements or cultural-artistic forms: art forms and public inquiries are centered around the Screen's ability to influence the neuropsychological receptors of the person, leading to the emergence of the neuroart direction ${ }^{6}$ [7].

Neuroart is a modern art tool that combines the distinctive expressive capabilities of sound, images, and text to form an idea that is projected into the human subconscious, using the numerous means of modern technology represented in the image of the Screen (phone, computer, television, etc.). In this way, the person through the Screen accumulates in his subconscious information, which extrapolates to the outside world, which forms the new reality of humans. Neuroart is the creation of internal images in the human subconscious under the influence of sensory life experience, and not always, this image may find an external form but may be empathetic ${ }^{7}$ [6].

The mentioned ideas are connected with the new view of the personality of the artist in the study of Victor Stepuryk, which presents artistic introversion as an internal creative impulse, born in the artist's subconscious or as intentionality, aimed at the inner world, experience ${ }^{8}$ [19]. As a result, people find themselves outside of society in a self-created world in which art is identified with the inner state reflected in external images. This is also seen in the example text, which in the sense of subtext is an image ${ }^{9}$ [18], and therefore touches the thinnest neural layers. Thus, it leads to exploring the profound nature of human sensations and finding ways to influence the subconscious directly.

In some ways, the essence of the Screen is a powerful external stimulus that affects the individual as an individual, and more deeply, and the entire society. This can be correlated with the general state of the primitive environment, in which man adapted to the outside world, which also influenced him in various ways. Therefore, in both cases, the person is under the influence of external stimuli, which stimulate the constant search for external stimuli with the priority of emotional onset. We can only assume that a powerful impetus for the creation of rock drawings was a primarily emotional experience. Still, the modern diversity of Screen production shows the priority of the emotional factor. Thus, emotional demand determines the deepest layer of human essence, requiring more and more emotional stimuli.

In this context, the theory of Donald Hebb, the creator of artificial neural networks, according to which the human nervous system requires a continuous

${ }^{6}$ Karpov, V., Syrotynska, N. (2018). Medieval and contemporaneity world-visual and art parallels // Bulletin of the National Academy of Culture and Arts, 2, p. 143.

${ }^{7}$ Ibid,, p. 56.

${ }^{8}$ Stepurko, V. (2017). Vyjavy mystecjkoji introversiji u tvorchosti kompozytoriv Ukrajiny drughoji polovyny XX - pochatku XXI stolittja: dys. kand. myst.: 26.00.01. Kyjiv. NAKKKiM, p. 45.

${ }_{9}^{9}$ Soroka I., (2017). Pidtekst jak kateghorija scenichnogho movlennja: dys. kand. myst.: 17.00.02. Kyjiv. NAKKKiM, p. 154. 
flow of external stimuli is vital. This leads to the view of the particularly important role of art, which, since ancient times, has become a means of selfexpression. The creative thinking demonstrated in numerous rock paintings has been the earliest evidence of the emergence of man as a biological individual of homo sapiens, different from other species also at the level of instincts capable of self-preservation and reproduction. Therefore, due to the ability to reproduce the surrounding world, a person distinguished himself in it and for the first time, declared the ability to create.

Therefore, in the cave twilight, works of art called "eidetic images" were created and the etymological basis "eidos" or "image" most clearly manifested in antiquity in the philosophy of Platonism. In the context of such variability of human thinking, within the radically distant periods of the planes, we observe the diametric milestones of human evolution from the "eidetic" reproduction of the world to its cognition in the context of the ideal "eidos" of Platonic doctrine. Since then, we have seen a slow "slipping" into the emotionally effective visualizations of contemporary culture.

It should be noted that the Platonic "eidos" as the term of ancient philosophy embodies the special reality of the "realm of ideas" outside the symbolic cave, that is, the familiar sensual world, and symbolizes a particular transcendental world. Instead, "eidetic" belongs to the field of psychology and means the ability to reproduce images of objects in their absence accurately. This so-called "total recall" stored in memory by engaging all human sensations. Thus, the affinity of "eidos" and "eidetic" lies primarily in the ability to literally "see the invisible."

Eidetic memory must be completely inherent in children, and this type of memory dominated the primitive society. In a certain way, it is necessary to define the "image" itself as a structural model of human thinking and, accordingly, to explore more deeply the features of primitive art from the standpoint of the essence of rock images as artistic signs of manifestations of eidetic thinking. The signs that singled out a human in the cave during the caverns, and then, on the contrary, became the symbols by which man displayed his genetic unity. Instead, the modern man is again at the crossroads in search of the own "I" in the depths of the unconscious. In a certain way, the person who emerged from the original cave returned to his own symbolic cave - his own brain. And in this way, the concept of "eidos" has become a symbol of communication with both the surrounding and divine worlds, as well as with one's own brain, which creates vivid concepts in imagination, in dreams, or even in the moment of hallucinations.

The very beginning of a whole range of neuroscience has allowed us to move closer to identifying the major human brain stimuli that stimulate creative initiation and a sense of beauty over the last ten years. However, in this context, 
the experience of primitive culture, which for the first time intuitively defined the own presence in the language of rock images, is not sufficiently taken into account. Therefore, eidetic art requires a detailed study. As P. Kutsenkov writes: "Modern and caveman, despite all the differences between them, are still representatives of the same species, we have inherited many qualities of our ancestor - Cro-Magnon, in particular, the ability to create graphic images. Therefore, we can assume that something is preserved from the psychophysiological mechanism that triggered these actions. It is amazing that a modern man, contemplating the rock images of South Africa, Sahara, Central Asia, or any other point on Earth, is usually able to "understand" them. And this is not about a correct interpretation of the meanings of any form. Specific values (if there are any) are often left unencrypted. The point is different: we do not feel an emotional gulf between ourselves and those who have ever painted on rocks" ${ }^{10}$ [12].

Therefore, emotional perception is not limited to time frames and talks to us today. Thus, the human brain is capable of creating similar imagery models at a distance, reflecting certain phenomena or things. This is confirmed by artifacts created by different peoples in different parts of the world, but similar in forms, such as the Egyptian and Mayan pyramids, mounds, mounds of English Stonehenge, and, for example, its Ukrainian counterpart to the Pre-Christian era in the village of Terlipolis.

Famous anthropologist Claude Levi-Strauss also noted coincidences in different cultures, so the main conceptual focus of his work was to analyze the structures of thinking and a social life that was not dependent on individual consciousness and choice. Based on studies of social and cultural structures, Levi-Strauss also emphasized the particular need to find the laws of order that underlie various beliefs and institutions. On this basis, he resorted to myths that were both systems of abstract relations and objects of aesthetic contemplation ${ }^{11}$ [13]. However, the period was preceded by the art of the Paleolithic, which did not speak the language but left inherited extremely vivid images of the surrounding world, including animals.

Such artistic accuracy is related to the peculiarity of a Paleolithic person who did not speak the language. This statement was supported by the British psychologist Nicholas Humphrey, who, on this basis, came to believe that the person, before the ability of verbal communication, began to draw, and this determined the specifics of the art of this era.

It is essential to relate the phenomenon of Paleolithic art to the mnemonic function of human thinking, a memory that allowed us to reproduce images more accurately and more vividly than our contemporaries. Therefore,

${ }^{10}$ Kutsenkov, P. (2007). Psikhologiya pervobytnogo i traditsionnogo iskusstva. Moskva: Progress-Traditsiya, p. 240.

${ }^{11}$ Levi-Stros, Zh.-K. (1999). Pervobytnoe myshlenie. Moskva, p. 27. 
it is logical to assume that the memory mechanism was somewhat different from ours, and it received the definition of "eidetism," which is a specific type of memory, which allows reproducing in all details with striking brightness. Eidetic memories are different from ordinary memories in that they will enable us to perceive the image in its absence. Physiologically, it is believed that this trait is associated with excessive excitation of the visual analyzer, which occurs in children up to 2 years of age and is a throwback in adults. The main feature of modern man's memory is not the photographic fixation of reality pictures but the classification, sorting, and processing of the maximum amount of information, first of all, verbalizing contextual connections. Therefore, the lack of language can explain the vivid naturalism and affective-emotional mood of Paleolithic art, which is mainly related to hunting subjects.

The characteristics of Paleolithic eidetic paintings make it possible to distinguish their characteristic features, in particular, the complete isolation of the images except for the connections by relevance, the lack of classification by a generalization of activity. Therefore, the organization of groups of rock drawings occurred only in a way that can be defined as similar metonymic elements approach only by the method of relevance as if strung one after another canine. Similar to Altamira's Great Plaque, numerous and particular individuals of buffaloes, tours, and boars are depicted, completely ignoring each other and selected on the principle of a simple relevance.

It is worth noting that a precise analog of this principle is the contemporary collage that emerged in the early twentieth century and referred to the artistic movement of Dadaism, which belonged to a certain kind of anarchic worldview $^{12}$ [2]. Dadaism fundamentally rejected any meaning, prompting meaningful anarchy, which led to the idea of collage as a combination of heterogeneous elements glued to the base. This technique was further applied in painting. Due to features such as structural fragmentation and the lack of a definite composition, the visual collage is close to rock images, which, again, operates by the method of contacting models on a plane.

Features of Paleolithic art include such features as the ability to recognize non-verbal stimuli, evaluate spatial relationships, determine the similarity, differences, and physical identity of images. The paleolithic man had visual-spatial analysis, sequence, the simultaneity of perception, and, accordingly, specific recognition. The visual perception of the primitive man lacked only those qualities that were inherently associated with verbalization, so eidetic naturalism does not fit the modern concept of the image. There was a

\footnotetext{
${ }^{12}$ Bila, A. (2010). Sjurrealizm. Kyjiv, p. 208 s.
} 
lack of an individual ability to "transcribe," a necessary condition for creating images and writing ${ }^{13}$ [12].

In this context, it is worth recalling Ernst Kassirer's belief that primitive language did not express thoughts and ideas but feelings and affect ${ }^{14}$ [9]. Therefore, Paleolithic images could have no other "meaning" and "meaning" other than to be a continuation of "feelings and affections" directly generated by tactile or visual sensations. And only in the Mesolithic images will become signs, and replaced by feelings and affect will come to the concept. During this period, in the process of mastering the language, holistic perception of the world will undergo a phase of differentiation into constituent elements. This is evidenced by the discrete display of rock objects and the beginning of the perception of single objects in the context of their primary purpose.

Thus, over the millennia, we have been displaying the main features of the Stone Age culture, most clearly manifested in the visual arts. In this context, an important factor was the imagination, the invisible force that determines the world and fills it with aesthetic content. Throughout the long existence of the human species, imagination first inspires creativity. Still, at the same time, it becomes a symbolic medium of information that migrates from one system of signs to another in the boundless expanses of human consciousness. Hence, the interest in the neural depths of human thinking limited only by the possibilities of one's imagination.

\section{Homo parvus mundus est ${ }^{15}$ : imagination as a neuroinstrument of knowledge and creation of the world}

For centuries, the great minds of humanity have tried to explain the essence of human being, because our presence in the world is marked not only by a persistent adaptation to biological conditions with increasing chances of survival but by forms of knowledge and creation of the same world. This explains the uniqueness of homo sapience, endowed with irrational consciousness and thinking, the ability to make free choices and to feel moral responsibility for the consequences. These qualities and defined the essence of man in religion, philosophy, science, and art, which collectively reflect the various forms of manifestation of the invisible part of the human soul - the imagination.

The identification of the imagination with the invisible force that determines the world entirely correlates with the efforts of a person to find the

${ }^{13}$ Kutsenkov, P. (2007). Psikhologiya pervobytnogo i traditsionnogo iskusstva. Moskva: Progress-Traditsiya, p. $156 \mathrm{s.}$

${ }^{14}$ Kassirer, E. (2002). Filosofiya simvolicheskikh form. T.2. Mifologicheskoe myshlenie. Moskva - Sankt-Peterburg, p. 121.

${ }^{15}$ Human is a small world (microcosm), translated by Andriy Sodomora. 
way to knowledge of him/herself. Thus, the focus is on the notion of "imagination" as a symbolic toolkit of neural structures of the human brain that activate innovative ideas. It is worth noting that modern researchers of genetic codes are divided into two camps - supporters of physiological or anatomical features of a human. A similar parallel can be seen in the ability of humans to experiment at the level of the human imagination. In both cases, content and form have the potential to change, so that in this way, one gets some leverage on reality. The mentioned issue is expressed through the simple schemes, the first of which demonstrates the functioning of human organisms at the gene level ${ }^{16}$ [14]: DNA - RNA - PROTEIN or GENE encodes the MESSAGE to create the FUNCTION. In this way, the message-information as an intermediary is located between the physical level of the gene and the functionconsequence. Similarly, one can display the connection of elements in the plane of human thinking associated with creativity: IRRITANT IMAGINATION - FORM. With the help of this scheme, we observe the cooperation of the "stimulus" that instills "imagination" as a way of producing new content, the reflection of which stimulates the emergence of more and more new artistic forms.

It is important to note that the scheme mentioned above is coherent with even deeper comprehension associated with the most valuable gift man possesses - the freedom of choice, which is specified by Stephen Cowie: "There is a time gap between stimulus and reaction to it. In this gap, we have the freedom and the right to choose our reaction. Development and our happiness depend on this choice" ${ }^{17}$ [11]. In this way, the freedom of choice poses an intermediate stage between the determinism of external circumstances and the probable reaction to them: STIMULATION - FREEDOM OF CHOICE REACTION.

The realization of one's freedom not only changes one's person and his belief in the own capabilities but also makes him responsible for the own actions, develops his inner strength and potential.

If we compare all the schemes on the same plane, we get three options for understanding the human capabilities of the essential central intermediary, which is characterized by the variability and function of the coordinator between the two sides of the cause and effect relationship:

\begin{tabular}{|c|c|c|}
\hline GEN & MESSAGE & FUNCTION \\
\hline IRRITANT & IMAGINATION & FORM \\
\hline STIMULATION & FREEDOM OF CHOICE & REACTION \\
\hline
\end{tabular}

\footnotetext{
${ }^{16}$ Mukerdzhi, C. (2017). Gene. An extraordinary story, Kharkiv, p. 34.

${ }^{17}$ Kovi, S. (2017). Eighth habit. From efficiency to grandeur. Kharkiv, p. 69.
} 
Thus, a gene with a sophisticated mechanism of internal molecular bonds (DNA, RNA) at the biological level, an stimulus embodied in the neural chains of the brain (neuro-instruments) and the stimulus as external factors of human life (living conditions, education, etc.), together form the basis the structure of human functioning in society. Instead, a person endowed with the ability to create and choose designs the own parvus mundus - the surrounding space and personal reality. In this way, it finds itself in a symbolic mirror - in opposition to the openended planes of time-space, which are in constant interaction within the limits of the own reflection. This happens through the prism of the functioning of consciousness, producing the figurative-semantic image of the world, or even the ideal cultural space, in which the deepest levels of human being are intersected. One of the ways to know these processes is to get acquainted with the essence of neuroart, which is based on the ability to display and reflect the world around us through imagination ${ }^{18}$ [8]. Hence, let's note the most critical signs of imagination that are: the mechanism of communication among stimuli of public demand and expected result; an intellectual game tool, the essence of which manifests itself in the skill of metaphorical constructing of creative concepts; a form of subjective reaction to the world, reflected by artistic means; a method of knowledge and change of personality of a person. In this context, imagination appears to be the most productive motivator of human self-development and the achievement of integrity.

Throughout the long existence of the human species, the imagination demonstrates the particular forms of functioning and purpose, appears as a symbolic carrier of information migrating from one system of signs to another in the infinite spaces of human consciousness. Hence, such interest in neural measurements of the possibilities of rational thinking reflected in the cooperation of the following factors:

1. Historical - a person relies on experience, preserved in the subconscious of humankind. Thus, there is a separate scientific direction of neuroarthistory, proposed and presented in the studies of John Onians's historian of art ${ }^{19}$ [15; 16]. The scientist notes the shortcomings of the European-centered limitation of the history of art and points to the need to expand the prospect of a world dimension with simultaneous deepening during the birth of man as an individual. The scientist believes that the neuroscience of art can combine the latest proposals of the humanistic sciences, such as bioghumanistics, posthumanism, humanistic non-anthropocentric, etc. He notes the crucial importance of the development of technology to deepen knowledge of the human brain: computed tomography,

${ }^{18}$ Karpov, V., Syrotynska, N. (2018). Neuroart in the context of creativity // Bulletin of the National Academy of Culture and Arts, 1, pp. 21.

${ }^{19}$ Onians, J. (2007). Neuroarthistory: From Aristotle and Pliny to Baxandall and Zeki, Yale, 2007; Onians, J. (2017). European Art: A Neuroarthistory. Yale. 
positron emission tomography, magnetic resonance imaging, and functional magnetic resonance, which allows you to control neuronal activity, detect the principles of their development and the formation of links between them. The researcher determines the key to his theory of the phenomenon of plasticity, which is interpreted as a permanent transformation of the brain in the process of learning and adaptation, and on this basis formulates the concept of neuroplasticity - the ability of the brain to change and create new neural bonds in accordance with the changing environment and stimuli that acquire various forms of stimulation (images, sound, color, movement) ${ }^{20}[10]$.

J. Onians's historical approach is based on the conviction that from the time of the ancient times the artists were interested in the mechanisms of perception of beauty, so the axis of evolution was the belief in the unconscious knowledge that the artist owns in the context and influence of the unconscious experience. In this way, neuroscience offers not only a new thinking model, which summarizes the elements that make up the concept of subjectivity but is also a convenient tool/mediator, through which one can study this subjectivity. Onians is a supporter of an individualistic approach to the development of art history since he believes that the subjective nature of the individual contributes to the formation of the neural network. And by this experience, reconstructed even after thousands of years, one can find the causes of the unconscious inspiration of the creators. Therefore, the first place in the neuroscientist art of the researcher is such basic concepts as experience and subjectivity. The first is the active action of stimuli that form the neural structure of the human brain, and the second - perception, comprehension, and persuasion.

2. Intellectual - based on the personal approach of the artist to the reflection in the works of art of the own ideological principles. Said feature is particularly characteristic of art XX - XXI centuries deliberately focused on finding new forms of ideological and artistic beliefs, manifested in numerous variety of different creative fields: Secession, Art Nouveau, Symbolism, Impressionism, Fauvism, Cubism, Dadaism, Expressionism, Futurism, Imagism, Tachism, Orphism, Surrealism, Constructivism, Abstractionism, Pop Art, Op-Art, Primitivism and others. All of them were united by at least one important feature - the rejection of external similarity to life realities, so the following forms of thinking were metaphorical, associative, fantastic imagery, sensuality, abstraction, which is collectively associated with the interpretive potential of human intelligence in the process of experimentation with "flows of consciousness", which entirely fits into the modern prediction of the future ${ }^{21}[8]$.

${ }^{20}$ Kędziora, Ł. (2014) Niezauważona i rewolucyjna neurohistoria sztuki, sztuki // Acta Universitatis Nicolai Copernici, 45, Toruń, pp. 240.

${ }^{21}$ Karpov, V., Syrotynska, N. (2018). Neuroart in the context of creativity // Bulletin of the National Academy of Culture and Arts, 1, p. 27. 
3. Aesthetic - reveals the peculiarities of human awareness of various forms of beauty that are demonstrated in different time periods. Instead, a new science of neuroesthetic attempts to formulate the general laws of a person's sense of aesthetic pleasure. Neuroscientist Semir Zeki, who focuses on forms of perception of images of visual information, is based on the study of neural states recorded at the time of the survival or creation of works of $\operatorname{art}^{22}$ [22; 3]. Methods and techniques of empirical sciences serve as a narrative and explanation of aesthetic experience, and neuroesthetics is interpreted as an interdisciplinary science with the involvement of researchers in the field of philosophy, psychology, history of art, and neurology, with the participation of a visual examination of the cerebral cortex. In this way, the relationship between neural structures and processes shaping aesthetic perception is studied. Subsequently, on this basis, Semir Zeki and Vilayanur Ramachandran constructed the corresponding theories ${ }^{23}$ [17]. Thus, neuroesthetics became a department of experimental aesthetics - an interdisciplinary form of cooperation between cognitive science, psychology, philosophy, and neurology, which studies the structure and functioning of the nervous system. And in the year 2008, the Association of Neuroesthesiology, which belongs to the Charité University Medicine in Berlin, was founded in Berlin. Its aim was to cooperate with scientists and artists to study art and its perception.

Zeki formulates two fundamental principles of visual perception: constancy and abstraction. The first is based on the ability of the brain, despite the changes that occur when processing visual stimuli (distance, illumination, viewing angle, etc.) to store information about the permanent and essential features of the object. Instead, the law of abstraction testifies to the ability of the brain to hierarchical coordination, applied to individual numerical elements, the effective processing of visual stimuli, and the ability to snatch abstract concepts from individual images. The role of imagination in such communication is essential since it not only contributes to the comprehension of multi-valued artistic works but also allows creatively to add directly non-reciprocal works, which will enable you to get a sense of satisfaction.

4. Emotional-empathic - associated with the discovery of Giacomo Rizzolatti mirror neurons in 1990. Mirror neurons are a particular type of motor cells that are excited when performing or observing a specific action. In this way, along with the ability to inherit, there is a specific emotional state that John Onians called empathic intuition. The researcher draws attention to the visual and unconscious experience that can be understood by knowing the mechanisms of

${ }^{22}$ Zeki, S. (1999). Inner Vision: An Exploraton of Art and the Brain. Oxford [in English]; Bremer, J. (2013). Neuroestetyka: czy przyszłość estetyki leży w neuronauce, Estetyka i Krytyka, № 1, Warszawa, p. 18.

${ }^{23}$ Ramachandran, V. (2015). Brain recounts: What makes us human, Moscow, p. 45. 
perception and reaction - empathy, as a new way of expressing and, above all, the experience of works of $\operatorname{art}^{24}$ [4]. These persuasions of J. Onians renewed interest in the subjective element of emotion in the context of the history of art, and at the present stage, empathy is a category current not only in the neuro historiography of art but in most disciplines with the prefix of the neuro. Emotions seem especially crucial for artistic perception, as they bring the interpreter closer to the described work of art on an entirely different level than merely a methodological discourse or historical context. The mentioned issue reflects the main content of empathy - the ability of a person to sincere sympathy, to the comprehension of being through supreme emotional enlightenment.

The mentioned structure in the context of neuroscience approach to the worldview is mostly heuristic, and research in this area does not abolish the values of the art itself and does not weaken the sensations of passion for artistic creativity and communication with art. On the contrary, the imagination enhances emotional vulnerability, percepts the inner personal world, arouses the inherent qualities of a person, and prompts action. In a certain way, imagination is an authoritative source of energy hidden in the depths of human consciousness, closely related to the inexhaustible cosmos, in which homo parvus mundus est.

\section{CONCLUSIONS}

The history of human evolution takes into account not only the forms of adaptation to the environment but also the ways of knowing and reflecting attitudes to the surrounding world. Outlining the principles of the evolution of aesthetic perception from the standpoint of socio-cultural priorities of different historical stages shows that it is the experience of neuro-aesthetics that determines the peculiarity of the human psyche, which was formed within the opposition of moral principles. An additional characteristic component was the emotional beginning formed in the primitive days in the process of eidetic perception of the world in the absence of language skills. Thus, over the millennia, we have found significant parallels to images and symbols, to means and aesthetic preferences, and hence to artistic trends that are distant within the time.

The genesis of the culture of humankind demonstrates the tangible connection of modern worldviews with the unique capabilities of technical innovation, which requires the introduction of contemporary terminology. The term neuroart is proposed, which accumulates contemporary artistic means, reflected in a combination of distinctive expressive capacities of sound, image,

${ }^{24}$ Freedberg, D. Gallese V. (2007). Motion, emotion and empathy in esthetic experience // Trends in Cognitive Science, 11, Phaidon, 2007, p. 198. 
and text, which collectively project a particular idea into the human subconscious through various means of modern technology.

Neuroart answers the question of the nonlinear development of art. According to the mentioned principles, the perfection of the form of primitive art and art of the 21st and other earlier centuries is explained by the biological constancy of a human and one's brain. In understanding the biological development of man, as a species, it has not changed in the tens of thousands of years of its existence. The brain, with the richness of its functional features, remained biologically unchanged. Thus, the person, one's mind and brain are stable as well as permanent. Hence, the mentioned issue explains the harmony of the forms of art distant within time. The art is what a person imagines. The basis of an individual's imagination is an aesthetic experience. According to the concept of modern humanistic aesthetics, beauty is in the eye of the beholder. There is an internal theatricalization - the unfolding of complex images and their combination within themselves. The transition from aesthetic experience to the imaginative vision is an act of creativity of the neuroart.

\section{SUMMARY}

In the article, based on the analysis of scientific literature, the question of aesthetic features of the artistic progress of humanity from neuro-aesthetic perception is considered. The evolution of creative inspirations in the context of neuroscientific research, the essence of aesthetic values from the standpoint of the laws of neuroesthetics and neuroart are investigated. The historiography of neuro-art and neuro-aesthetics is represented by a wide range of authors who have researched in many synthetic fields of art and neuroscience. The methodological basis for the study of the neuroart is a comprehensive approach to the research of problems that cover art analysis, due to the relevance of an in-depth review of art as a means of knowing man of the world; cultural analysis of processes and phenomena of human creativity; structural-system method of source analysis; a historicalcomparative method of analyzing the peculiarities of styles in the directions along a long evolutionary process of forming the aesthetic foundations of artistic progress; a heuristic method that helps to identify the patterns and symbols that form the basis of the neuroart, which ensures the integrity and systematic evolution of culture and art; hermeneutics of the artistic coding of worldview concepts of human being. The scientific novelty of the research determines the priority of a sophisticated understanding of art during a long historical period of formation and development from the standpoint of achievements of neurophysiology and the structure of artificial intelligence. The idea is substantiated that the results of understanding the essence of neuro-art can serve as an essential component in the study of contemporary 
cultural and artistic achievements as well as in determining the value categories of hyper-information society. The work extends the existing source base for further studies of the artistic creation of humankind in different historical periods from the standpoint of the neuroart and the neuroesthetic approach.

\section{REFERENCES}

1. Bezughla, R. I. (2019). Ghlamur u jevropejsjkij khudozhnij kuljturi: istorychna dynamika ta formy : dys. na zdob. nauk. stup. d. myst. : spec. 26.00.01 - teorija ta istorija kuljtury (mystectvoznavstvo). K.: Nacionaljna akademija kerivnykh kadriv kuljtury i mystectv. 485 s. [in Ukraine].

2. Bila, A. (2010). Sjurrealizm. Kyjiv. 208 s. [in Ukraine].

3. Bremer, J. (2013). Neuroestetyka: czy przyszłość estetyki leży w neuronauce, Estetyka i Krytyka, № 1, Warszawa, 9-28 [in Polish].

4. Freedberg, D. Gallese V. (2007). Motion, emotion and empathy in esthetic experience // Trends in Cognitive Science, 11, Phaidon, 2007, 197-202 [in English].

5. Girts, K. (2004). Interpretatsiya kul'tur. Moskva. [in Russian].

6. Karpov, V., Syrotunska, N. (2019). NEUROARTES: the Art of the Cognition of the Man. Kyiv. NAKKKIM.106 s. [in Ukraine].

7. Karpov, V., Syrotynska, N. (2018). Medieval and contemporaneity world-visual and art parallels // Bulletin of the National Academy of Culture and Arts, 2, 117-183. Kyiv [in English].

8. Karpov, V., Syrotynska, N. (2018). Neuroart in the context of creativity // Bulletin of the National Academy of Culture and Arts, 1, 21-36. Kyiv [in English].

9. Kassirer, E. (2002). Filosofiya simvolicheskikh form. T.2. Mifologicheskoe myshlenie. Moskva - Sankt-Peterburg. 280 s. [in Russian].

10. Kędziora, Ł. (2014) Niezauważona i rewolucyjna neurohistoria sztuki, sztuki // Acta Universitatis Nicolai Copernici, 45, Toruń, 223-252 [in Polish].

11. Kovi, S. (2017). Eighth habit. From efficiency to grandeur. Kharkiv [in Ukrainian].

12. Kutsenkov, P. (2007). Psikhologiya pervobytnogo i traditsionnogo iskusstva. Moskva: Progress-Traditsiya. 256 s. [in Russian].

13. Levi-Stros, Zh.-K. (1999). Pervobytnoe myshlenie. Moskva. [in Russian].

14. Mukerdzhi, C. (2017). Gene. An extraordinary story, Kharkiv [in Ukrainian].

15. Onians, J. (2007). Neuroarthistory: From Aristotle and Pliny to Baxandall and Zeki, Yale, 2007 [in English]. 
16. Onians, J. (2017). European Art: A Neuroarthistory. Yale [in English].

17. Ramachandran, V. (2015). Brain recounts: What makes us human, Moscow [in Russian].

18. Soroka I., (2017). Pidtekst jak kateghorija scenichnogho movlennja: dys. kand. myst.: 17.00.02. Kyjiv. NAKKKiM. 163 s. [in Ukraine].

19. Stepurko, V. (2017). Vyjavy mystecjkoji introversiji u tvorchosti kompozytoriv Ukrajiny drughoji polovyny XX - pochatku XXI stolittja: dys. kand. myst.: 26.00.01. Kyjiv. NAKKKiM. 204 s. [in Ukraine].

20. Stolyar, A.D. (1985). Proiskhozhdenie izobrazitel'nogo iskusstva. M.: Iskusstvo. [in Russian].

21. Yatsenko, S.A. (2017). Iskusstvo u poroga inogo mira // Vestnik Rossiyskogo gosudarstvennogo gumanitarnogo universiteta, № 10. S. 269-279. [in Russian].

22. Zeki, S. (1999). Inner Vision: An Exploraton of Art and the Brain. Oxford [in English].

Information about the author: Karpov V. V., orcid.org/0000-0002-3446-9187 Doctor of History, Head of the Department of Art Expertise National Academy of Culture and Arts Management 9, Lavrska str., Bldg. 15, 01015, Kyiv, Ukraine 